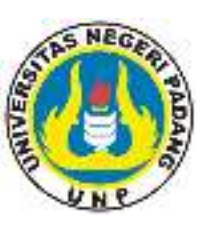

\title{
KESULITAN MAHASISWA TAHUN MASUK 2018 DALAM MEMAHAMI TEKS BAHASA JEPANG
}

\author{
Hanifah Nurulhuda ${ }^{1}$, Damai Yani ${ }^{2}$ \\ ${ }^{1}$ (Mahasiswa Pendidikan Bahasa Jepang, Bahasa dan Sastra Inggris, Fakultas Bahasa dan Seni, \\ Universitas Negeri Padang). \\ ${ }^{2}$ (Dosen Pendidikan Bahasa Jepang, Bahasa dan Sastra Inggris, Fakultas Bahasa dan Seni, \\ Universitas Negeri Padang). \\ Email Penulis: hanichan70@gmail.com
}

\begin{tabular}{lc}
\hline \multicolumn{3}{l}{ Sejarah Artikel } \\
\hline Submit & $: 2020-10-29$ \\
Diterima & $: 2021-03-19$ \\
Diterbitkan $:$ : 2020-06-09
\end{tabular}

Kata Kunci:

Difficulty, Understandin, Japanese text.

\begin{abstract}
In learning Japanese, understanding Japanese text is included in the Dokkai course. Dokkai is one of the compulsory courses that students of the Japanese language education study program, Padang State University, have to take for approximately 3 years or 6 semesters. The Japanese text does not use romaji letters, but uses 3 different types of letters, namely hiragana, katakana and kanji which make Japanese text difficult to understand. The large number of Japanese language education study program students in 2018 experienced difficulties in understanding Japanese language texts. The purpose of this study is to describe the difficulties of students in understanding Japanese text. This research is a quantitative descriptive study. The sample used in the study was 39 students. The data collection technique in this study used a questionnaire and used a Likert scale formula. While the data analysis technique is descriptive with a percentage. The results of this study found the difficulties experienced by students, among others, the sub-indicator of kanji with a percentage of $74.35 \%$. In the linguistic indicator, students have difficulty with the vocabulary subindicator with a percentage of $63.7 \%$, sentence patterns with a percentage of $64 \%$ and meaning with a percentage of $61.7 \%$. Then in the indicator of student spelling and sound patterns, only difficulty in the sub-indicator voicing/intonation in reading with a percentage of $63.6 \%$.
\end{abstract}

\footnotetext{
${ }^{1}$ Mahasiswa Prodi Pendidikan Bahasa Jepang FBS UNP lulus pada tanggal 10 November 2020

${ }^{2}$ Dosen Prodi Pendidikan Bahasa Jepang FBS UNP
} 


\section{PENDAHULUAN}

Seorang pembelajar bahasa harus menguasai keterampilan yang baik dalam berbahasa guna menunjang keterampilan berkomunikasi yang baik dengan orang asing. Keterampilan pokok yang harus dimiliki seorang pembelajar bahasa ada empat, yaitu keterampilan mendengar, berbicara, membaca, dan menulis. Salah satu bahasa yang di pelajari di Indonesia adalah bahasa Jepang. Bahasa Jepang adalah salah satu bahasa yang memiliki ciri khas yang unik baik dari unsur kebahasaan, kosakata dan sistem gramatik (Lidra dkk, 2018). Menurut Sutedi (2009), pembelajar bahasa Jepang dituntut untuk dapat menguasai empat keterampilan berbahasa mulai dari berbicara (hanasu ginou), membaca (yomu ginou), mendengar (kiku ginou) dan menulis (kaku ginou.). Membaca merupakan kegiatan atau proses kognitif yang berupaya untuk menemukan informasi yang terdapat dalam tulisan (Dalman, 2013). Pada pembelajaran bahasa Jepang pemahaman teks bahasa Jepang termasuk ke dalam mata kuliah dokkai.

Dokkai adalah salah satu matakuliah wajib yang harus diikuti oleh mahasiswa program studi pendidikan Bahasa Jepang Universita Negeri Padang selama kurang lebih 3 tahun atau 6 semester. Pada teks bahasa Jepang tidak menggunakan huruf romaji, tetapi menggunakan 3 macam huruf yang berbeda, yaitu huruf hiragana, katakana dan kanji. Selain itu mahasiswa juga harus dapat menerjemahkan dan memahami isi teks tersebut, itulah hal yang menyebabkan mahasiswa merasa kesulitan. Selain itu Aspek-aspek yang harus dikuasai oleh mahasiswa untuk memahami teks menurut (Tarigan, 2016) adalah (1) Pengenalan bentuk huruf, (2) Pengenalan unsur-unsur linguistik (fonem/grafem, kata, frase, pola klause, kalimat dan lain-lain) (3) Pengenalan hubungan/korespondensi pola ejaan dan bunyi (kemampuan menyuarakan bahan tertulis) (4) Kecepatan membaca bertaraf lambat. Hal inilah yang menjadi landasan peneliti menyusun indikator kesulitan dalam memahami teks bahasa Jepang.

Sebelum melakukan penelitian, peneliti telah melakukan studi pendahuluan tentang kesulitan memahami teks bahasa Jepang kepada mahasiswa tahun masuk 2018 dan 2019 melalu google from. Peneliti melalukan perbandingan dari hasil angket yang didapat dan memutuskan melakukan penelitian ini pada mahasiswa tahun masuk 2018 karena dari hasil angket tersebut bahwasanya 34 orang mahasiswa 73,5\% diantaranya merasa kesulitan dalam memahami teks bahasa Jepang.

Penelitian tentang faktor kesulitan memahami teks bahasa Jepang ini telah dilakukan oleh peneliti sebelumnya yaitu Ermawati (2013) dengan judul "Analisis Kesulitan Mahasiswa Semester VI dalam Memahami Teks Dokkai Tingkat Menengah Universitas Negeri Semarang". Menyimpulkan bahwa mahasiswa semester VI angkatan 2010 mengalami kesulitan ketika memahami teks bahasa Jepang yang diajarkan pada mata kuliah Dokkai Enshu. Kesulitan yang dialami ketika memahami teks antara lain: kosakata, kanji, dan pola kalimat yang kurang dipahami oleh mahasiswa serta kurangnya kesadaran dalam belajar. Sama halnya dengan mahasiswa prodi pendidikan bahasa Jepang Universitas Negeri Padang tahun masuk 2018 juga merasa kesulitan untuk memahami teks bahasa Jepang. Selain itu, Belum ada dokumentasi tentang kesulitan mahasiswa dalam memahami teks bahasa Jepang Dari penjelasan tersebut, maka peneliti tertarik meneliti tentang "Kesulitan Mahasiswa Tahun Masuk 2018 dalam Memahami Teks Bahasa Jepang" 
Tujuan dari penelitian ini adalah untuk mendeskripsikan kesulitan mahasiswa dalam memahami teks bahasa Jepang. Manfaat penelitian ini diharapkan dapat menjadi landasan atau masukan tentang kesulitan dalam memahami teks bahasa Jepang, sehingga mampu meningkatkan hasil belajar dengan baik.

\section{METODE PENELITIAN}

Metode penelitian ini merupakan penelitian kuantitatif. Menurut Arikunto (2010) mengatakan bahwa penelitian kuantitatif merupakan penelitian yang menggunakan angka, dimulai dari pengumpulan data, kemudian penafsiran data, dan terakhir ditampilkan hasilnya. Pendekatan yang digunakan dalam penelitian ini adalah pendekatan deskriptif. Pada penelitian deskriptif kuantitatif ini digunakan untuk mendeskripsikan data hasil angket kepada responden.

Populasi dalam penelitan ini adalah mahasiswa tahun masuk 2018 Program Studi Pendidikan Bahasa Jepang Universitas Negeri Padang yang terdiri dari 2 kelas yang berjumlah 64 orang. Sedangkan Teknik pengambilan sampel yang digunakan adalah teknik total sampling. Instrumen yang digunakan dalam penelitian ini adalah angket. Angket digunakan untuk mengetahui apakah mahasiswa mengalami kesulitan dalam memahami teks bahasa Jepang. Menurut Arikunto (2010) angket adalah sejumlah pertanyaan tertulis yang digunakan untuk memperoleh informasi dari responden dalam arti laporan tentang pribadinya atau hal-hal yang diketahui. Penelitian ini menggunakan validitas isi. Untuk menguji validitas isi digunakan dengan mendengarkan pendapat para ahli (judgment experrts). Analisis reliabelitas instrumen ini menggunakan rumus alpha Cronbarch. Angket disebar kepada mahasiswa melalui google form. Kemudian angket akan dianalisis menggunkan skala likert lalu menentukan interval penilaiannyan dan menginterpretasikan.

\section{HASIL DAN PEMBAHASAN}

\section{Temuan Penelitian}

Deskripsi data dalam penelitian ini adalah hasil yang diperoleh dari angket kesulitan mahasiswa tahun masuk 2018 prodi pendidikan bahasa Jepang Universitas Negeri Padang dalam memahami teks bahasa Jepang dalam mata kuliah shochukyuu dokkai zenhan yang berjumlah 39 orang responden. Pengumpulan data menggunakan instrument angket tertutup yang berjumlah 16 butir pertanyaan. Skor tiap butir pertanyaan dalam angket tersebut berkisar antara 5-1. Data penelitian ini diperoleh dengan memberikan angket yang dilaksanakan pada Jumat, 21 Agustus 2020 melalui google form. Data analisis yang diperoleh dari angket tersebut terdiri atas 3 indikator yang ada yaitu: (1) kesulitan dalam memahami huruf (2) kesulitan dalam memahami linguistik dan (3) kesulitan dalam pola ejaan dan bunyi. Dapat dilihat pada tabel dibawah ini: 
Data analisis

\begin{tabular}{ccc} 
Indikator & Interval & Persentase \\
\hline Huruf & Sedang & $47,6 \%$ \\
\hline Linguistik & Sulit & $64 \%$ \\
\hline Pola ejaan dan bunyi & sedang & $57,2 \%$ \\
\hline
\end{tabular}

Pengolahan data menggunakan bantuan goolge from Kemudian ditabulasikan dan dianalisis menggunakan analisis deskriptif persentase yang bertujuan untuk menggambarkan data penelitian dengan bentuk persen. Deskripsi data meliputi skor terendah, skor tertinggi dan rata-rata.

Berdasarkan deskripsi data di atas maka peneliti dapat menganalisis angket yang telah dikumpulkan sebelumnya. Langkah pertama yang dilakukan untuk mengetahui kesulitan mahasiswa tahun masuk 2018 prodi pendidikan bahasa Jepang Universitas Negeri Padang dalam memahami teks bahasa Jepang dalam mata kuliah shochukyuu dokkai zenhan adalah melakukan pengolahan data yang dikumpulkan sebelumnya dalam bentuk angka (skor) dan dianalisis dengan menggunakan rumus persentase yang akan dijelaskan per sub indikator yang ada. Adapun hasilnya dapat dilihat pada tabel hasil angket berikut:

\section{Indikator I (Kesulitan dalam Memahami Huruf)}

Salah satu indikator kesulitan mahasiswa dalam memahami teks bahasa Jepang adalah dalam memamahami huruf. Pada indikator ini terdapat 3 sub indikator. Deskripsi dari hasil analisis untuk indikator "huruf" dapat dilihat pada tabel di bawah ini:

\section{Indikator huruf}

\begin{tabular}{ccccc} 
Indikator & Sub indikator & Skor & Skor persen & Kategori \\
\hline \multirow{3}{*}{ Huruf } & Hiragana & 51 & $26,1 \%$ & Mudah \\
\cline { 2 - 5 } & Katakana & 83 & $42,5 \%$ & Mudah \\
\cline { 2 - 5 } & Kanji & 145 & $74,3 \%$ & Sulit \\
\hline \multicolumn{2}{c}{ Rata-rata } & $\mathbf{9 3}$ & $\mathbf{4 7 , 6 \%}$ & Sedang \\
\hline
\end{tabular}

Dari tabel di atas dapat diketahui bahwasannya rata-rata mahasiswa terhadap indikator huruf berada dalam kategori "sedang" yaitu dengan persentase $47,6 \%$ Selain 
itu, pada tabel di atas dapat diketahui bahwa dalam indikator huruf terdapat $3 \mathrm{sub}$ indikator yaitu hiragana, katakana, dan kanji. Adapun penjelasan mengenai sub indikator yang terdapat pada indikator tersebut adalah sebagai berikut:

\section{a. Sub Indikator Hiragana}

Pada sub indikator ini terdapat 1 pertanyaan yang menjabarkan kesulitan mahasiswa mengenai huruf hiragana. Dari analisis data yang telah dilakukan bahwasannya pada sub indikator hiragana termasuk pada kategori "mudah" Penjelasannya dapat dilihat pada tabel berikut:

\section{Sub indikator hiragana}

\begin{tabular}{ccccc} 
Sub indikator & Pertanyaan & Skor & $\begin{array}{c}\text { Skor } \\
\text { persen }\end{array}$ & Kategori \\
\hline Hiragana & $\begin{array}{c}\text { Apakah Anda merasa } \\
\text { kesulitan membaca } \\
\text { huruf hiragana? }\end{array}$ & 51 & $26,1 \%$ & Mudah \\
\hline 60 & $\mathbf{5 1}$ & $\mathbf{2 6 , 1 \%}$ & Mudah \\
\hline
\end{tabular}

Berdasarkan data tabel di atas dapat diketahui rata-rata kesulitan mahasiswa terhadap sub indikator hiragana adalah $26,1 \%$ berada dalam kategori "mudah". Hal ini menyatakan bahwa mahasiswa tahun masuk 2018 sangat baik dalam membaca huruf hiragana. Dalam sub indikator ini mahasiwa sudah hafal huruf hiragana dan tidak ada kesulitan yang berarti dalam hal ini. Karena ketika pada saat semester awal mahasiswa telah dituntut untuk menghafal huruf hiragana.

\section{b. Sub Indikator Katakana}

Pada sub indikator ini terdapat 1 pertanyaan yang menjabarkan kesulitan mahasiswa mengenai huruf katakana. Dari analisis data yang telah dilakukan bahwasannya pada sub indikator katakana termasuk pada kategori "mudah" Penjelasannya dapat dilihat pada tabel berikut:

\section{Sub indikator katakana}

\begin{tabular}{clccc}
$\begin{array}{c}\text { Sub } \\
\text { indikator }\end{array}$ & Pertanyaan & Skor & Skor persen & Kategori \\
\hline Katakana & $\begin{array}{l}\text { Apakah Anda } \\
\text { merasa } \\
\text { kesulitan } \\
\text { membaca huruf } \\
\text { katakana? }\end{array}$ & 83 & $42 \%$ & Mudah \\
\hline Rata-rata & $\mathbf{8 3}$ & $\mathbf{4 2 \%}$ & Mudah \\
\hline
\end{tabular}


Berdasarkan data tabel diatas dapat diketahui rata-rata kesulitan mahasiswa terhadap sub indikator katakana berada dalam kategori "mudah" yaitu dengan persentase $42 \%$. Hal ini menyatakan bahwa mahasiswa tahun masuk 2018 sangat baik dalam membaca huruf katakana. Sama halnya dengan huruf hiragana, huruf katakana juga telah dituntut untuk menghafal pada saat semester awal. Jadi tidak ada kesulitan yang berarti dalam hal ini.

\section{c. Sub Indikator Kanji}

Pada sub indikator ini terdapat 2 pertanyaan yang menjabarkan kesulitan mahasiswa mengenai huruf kanji. Dari analisis data yang telah dilakukan bahwasannya pada sub indikator kanji termasuk pada kategori "sulit". Penjelasannya dapat dilihat pada tabel berikut:

\section{Sun indikator kanji}

\begin{tabular}{clccc}
$\begin{array}{c}\text { Sub } \\
\text { indikator }\end{array}$ & \multicolumn{1}{c}{ Pertanyaan } & Skor & Skor persen & Kategori \\
\hline \multirow{2}{*}{ Kanji } & $\begin{array}{l}\text { Apakah Anda } \\
\text { merasa kesulitan } \\
\text { membaca huruf } \\
\text { kanji? }\end{array}$ & 148 & $75,9 \%$ & Sulit \\
\cline { 2 - 5 } & $\begin{array}{l}\text { Apakah Anda } \\
\text { merasa kesulitan } \\
\text { mengetahui arti dari } \\
\text { huruf kanji ketika } \\
\text { membaca teks } \\
\text { bahasa Jepang pada } \\
\text { mata kuliah } \\
\text { shochukyuu dokkai } \\
\text { zenhan? }\end{array}$ & & & \\
\hline & & & \\
Rata-rata & $\mathbf{1 4 2 , 8 \%}$ & Sulit \\
\hline
\end{tabular}

Berdasarkan data tabel diatas dapat diketahui rata-rata kesulitan mahasiswa terhadap sub indikator kanji berada dalam kategori "sulit" yaitu dengan persentase $74,3 \%$. Hal ini menyatakan bahwa mahasiswa tahun masuk 2018 merasa kesulitan dangan huruf kanji yang ada dalam shochukyuu dokkai zenhan. Dari tabel diatas juga dapat dilihat bahwa persentase skor mahasiswa sebanyak 75,9\% termasuk kedalam kategori "sulit" untuk pertanyaan "Apakah Anda merasa kesulitan membaca huruf kanji?". Hal ini dapat dinyatakan bahwa mahasiswa tahun masuk 2018 dalam membaca huruf kanji mengalami kesulitan. 


\section{Indikator II (Linguistik)}

Salah satu indikator kesulitan mahasiswa dalam memahami teks bahasa Jepang adalah Linguistik. Pada indikator ini terdapat 3 sub indikator. Deskripsi dari hasil analisis untuk indikator "linguistik" dapat dilihat pada tabel di bawah ini:

\section{Indikator Lingustik}

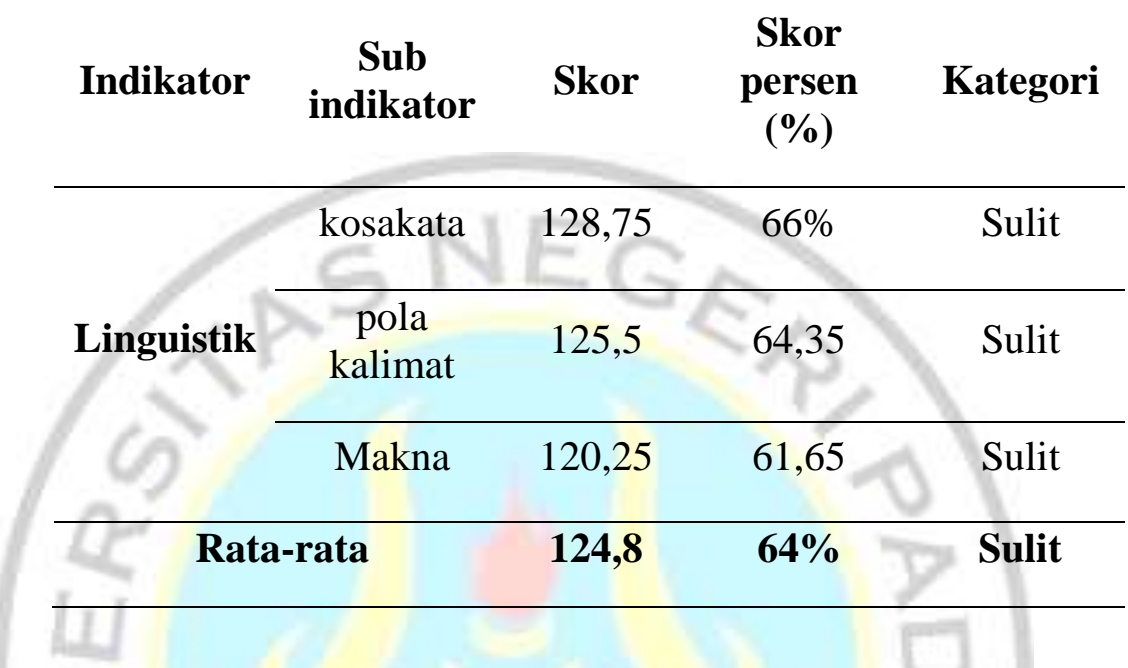

Berdasarkan data tabel diatas dapat diketahui rata-rata kesulitan mahasiswa terhadap indikator linguistik berada dalam kategori "sulit" yaitu dengan persentase 64\%. Selain itu, pada tabel di atas dapat diketahui bahwa dalam indikator linguistik terdapat 3 sub indikator yaitu kosakata, pola kalimat, dan makna. Adapun penjelasan mengenai sub indikator yang terdapat pada indikator tersebut adalah sebagai berikut:

\section{a. Sub Indikator kosakata}

Pada sub indikator ini terdapat 4 pertanyaan yang menjabarkan kesulitan mahasiswa mengenai kosakata. Dari analisis data yang telah dilakukan bahwasannya pada pada sub indikator kosakata termasuk pada kategori "sulit". Penjelasannya dapat dilihat pada tabel berikut:

\section{Sub indikator kosakata}

\begin{tabular}{clccc}
$\begin{array}{c}\text { Sub } \\
\text { indikator }\end{array}$ & \multicolumn{1}{c}{ Pertanyaan } & Skor & $\begin{array}{c}\text { Skor } \\
\text { persen }\end{array}$ & Kategori \\
\hline \multirow{2}{*}{ kosakata } & $\begin{array}{l}\text { Apakah Anda kesulitan } \\
\text { memahami kosakata baru } \\
\text { yang diajarkan disetiap } \\
\text { materi pada mata kuliah } \\
\text { shochukyuu dokkai zenhan? }\end{array}$ & 111 & $56,9 \%$ & Sedang \\
\cline { 2 - 5 } & $\begin{array}{l}\text { Apakah Anda kesulitan } \\
\text { menemukan arti kosakata } \\
\text { yang tidak anda ketahui }\end{array}$ & 135 & $69,2 \%$ & Sulit \\
& & & \\
\hline
\end{tabular}


ketika membaca teks bahasa

Jepang pada mata kuliah

shochukyuu dokkai zenhan?

Apakah Anda kesulitan mengetahui hubungan arti suatu kata dengan kata-kata lain

dalam kalimat?

Apakah Anda kesulitan mengetahui hubungan arti keseluruhan kata yang terkandung di dalam

kalimat?
128

$65,6 \% \quad$ Sulit

123

$63,1 \% \quad$ Sulit

\section{Rata-rata}

124,25

$63,7 \%$

Sulit

Berdasarkan data tabel diatas dapat diketahui rata-rata kesulitan mahasiswa terhadap sub indikator kosakata berada dalam kategori "sulit" yaitu dengan persentase 63,7\%. Hal ini menyatakan bahwa mahasiswa tahun masuk 2018 merasa kesulitan dangan kosakata yang disajikan di dalam shochukyuu dokkai zenhan. Dari tabel di atas juga dapat dilihat bahwa persentase skor mahasiswa sebanyak 56,9\% termasuk ke dalam kategori "sedang" untuk pertanyaan "Apakah Anda kesulitan memahami kosakata baru yang diajarkan disetiap materi pada mata kuliah shochukyuu dokkai zenhan". Pada pertanyaan ini mahasiswa tahun masuk 2018 setangah dari responden merasa kesulitan dan setengahnya lagi merasa tidak kesulitan. Ini artinya bahwa mahasiswa secara pribadi memiliki kemampuan yang berbeda dalam memahami kosakata baru. Ini juga akan berdampak pada mahasiswa dalam memahami teks bahasa Jepang. karena dalam teks bahasa jepang yang disajikan dalam shochukyuu dokkai zenhan selalu menyajikan kosakata baru untuk dipahami.

Pertanyaan selanjutnya yaitu "Apakah Anda kesulitan menemukan arti kosakata yang tidak anda ketahui ketika membaca teks bahasa Jepang pada mata kuliah shochukyuu dokkai zenhan?" dari tabel di atas dapat dilihat bahwa persentase skor mahasiswa sebanyak 69,2\% termasuk ke dalam kategori "sulit". Ini membukti bahwa banyaknya mahasiswa tahun masuk 2018 merasa kesulitan dalam menemukan arti kosakata baru. Hal ini akan menyebabkan mahasiswa tahun masuk 2018 kesulitan dalam memahami teks bahasa Jepang karena didalam teks bahasa jepang terdapat kosakata baru yang sulit di temukan artinya didalam kamus. Karena banyaknya kosakata yang terkadang tidak ada kosakata di dalam kamus yang ingin dicari.

Pada pertanyaan "Apakah Anda kesulitan mengetahui hubungan arti suatu kata dengan kata-kata lain dalam kalimat?" dari tabel di atas dapat dilihat bahwa persentase skor mahasiswa sebanyak $65,6 \%$ termasuk ke dalam kategori "sulit". Dalam perrtanyaan ini hubungan kata dengan kata-kata lain sangat mempengaruhi isi didalam 
teks bahasa Jepang shochukyuu dokkai zenhan. Tidak sedikit mahasiswa mengalami kesulitan dalam hal ini, karena didalam teks bahasa Jepang sangat berbeda dengan teks bahasa Indonesia yang mana kata dengan kata-kata lainnya memiliki makna yang berbeda namun saling berhubungan yang membuat mahasiswa kebingungan.

Untuk pertanyaan "Apakah Anda kesulitan mengetahui hubungan arti keseluruhan kata yang terkandung di dalam kalimat?" pada tabel di atas dapat dilihat bahwa persentase skor mahasiswa sebanyak $63,1 \%$ termasuk ke dalam kategori "sulit". Banyak mahasiswa tahun masuk 2018 kesulitan dalam hal ini karena minimnya kosakata yang diketahui dapat menyebabkan sulitnya mengetahui arti keseluruhan kata yang terkandung didalam kalimat tersebut. Mahasiswa terkadang hanya mengetahui satu atau dua kosakata didalam kalimat tetapi pada saat kosakata itu digabungkan menjadi kalimat yang utuh, mahasiwa menjadi kesulitan untuk mengartikannya.

\section{b. Sub Indikator kosakata}

Pada sub indikator ini terdapat 2 pertanyaan yang menjabarkan kesulitan mahasiswa mengenai pola kalimat. Dari analisis data yang telah dilakukan bahwasannya pada pada sub indikator pola kalimat termasuk pada kategori "sulit". Penjelasannya dapat dilihat pada tabel berikut:

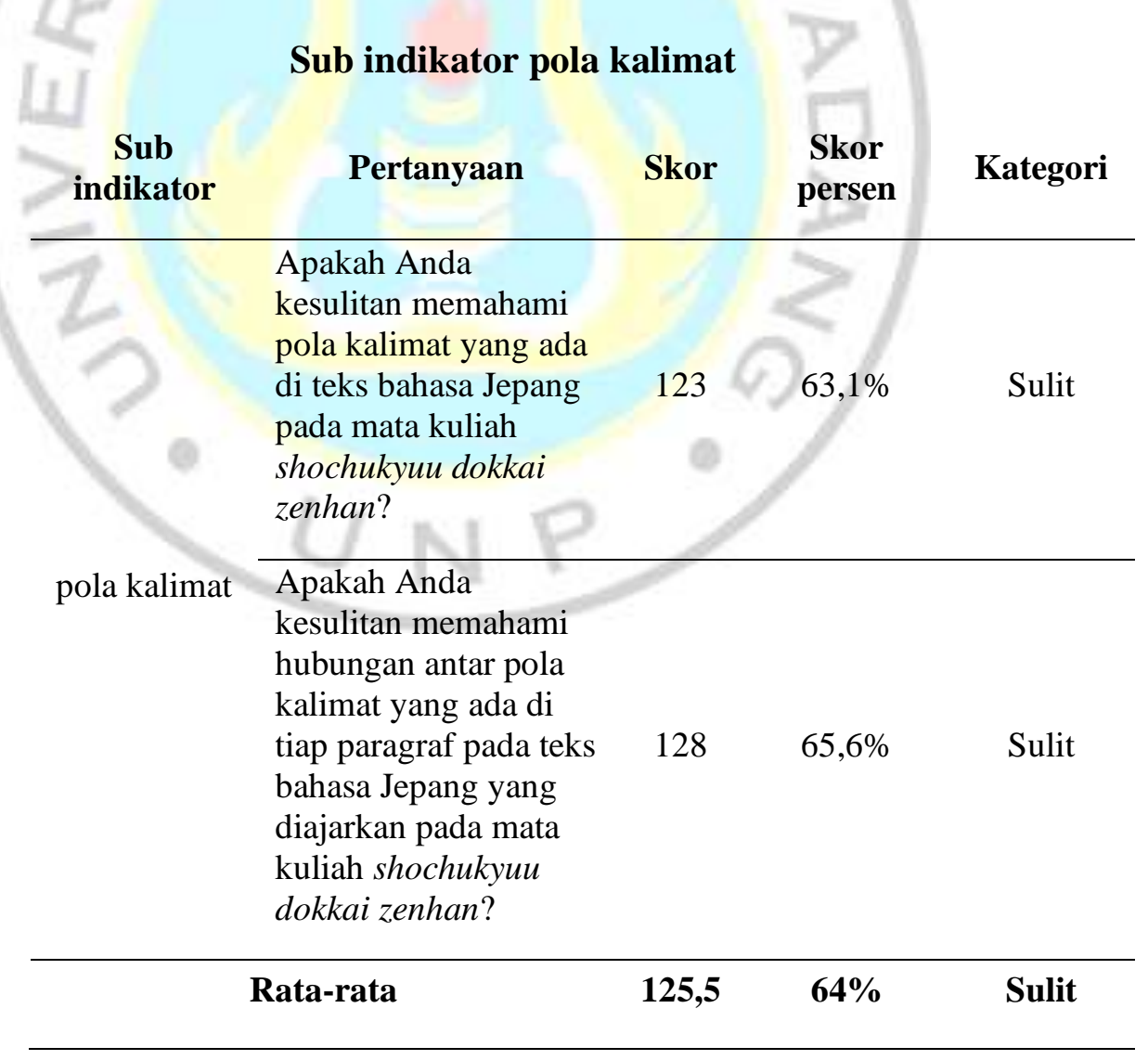

Berdasarkan data tabel diatas dapat diketahui rata-rata kesulitan mahasiswa terhadap sub indikator pola kalimat berada dalam kategori "sulit" 
yaitu dengan persentase $64 \%$. Hal ini menyatakan bahwa mahasiswa tahun masuk 2018 merasa kesulitan dangan kosakata yang disajikan di dalam shochukyuu dokkai zenhan. Dari tabel di atas juga dapat dilihat bahwa persentase skor mahasiswa sebanyak $63,1 \%$ termasuk ke dalam kategori "sulit" untuk pertanyaan "Apakah Anda kesulitan memahami pola kalimat yang ada di teks bahasa Jepang pada mata kuliah shochukyuu dokkai zenhan?" hal ini menyatakan bahwa mahasiswa tahun masuk 2018 kesulitan dalam memahami pola kalimat yang terdapat pada shochukyuu dokkai zenhan. Pola kalimat dalam teks bahasa Jepang berbeda sekali dengan bahasa Indonesia. Karena dalam teks bahasa Jepang terdapat partikel yang tidak ada di dalam teks bahasa Indonesia. Dan banyaknya pola kalimat yang harus dipelajari, ini membuat mahasiswa tahun masuk 2018 kesulitan setiap memahami teks bahasa Jepang tersebut.

Untuk pertanyaan "Apakah Anda kesulitan memahami hubungan antar pola kalimat yang ada di tiap paragraf pada teks bahasa Jepang yang diajarkan pada mata kuliah shochukyuu dokkai zenhan?" pada tabel di atas dapat dilihat bahwa persentase skor mahasiswa sebanyak $65,6 \%$ termasuk ke dalam kategori "sulit". Hal ini menyatakan bahwa mahasiswa tahun masuk 2018 kesulitan dalam memahami hubungan antar pola kalimat yang ada di tiap paragraf. Pola kalimat dalam setiap paragraf memiliki hubungan. Banyaknya pola kalimat yang terdapat pada setiap paragraf membuat mahasiswa kesulitan dalam memahaminya. Tingginya tingkatan pola kalimat yang disajikan maka semakin sulit untuk dipahami. Ini akan berdampak dalam memahami teks bahasa Jepang secara keseluruhan.

\section{c. Sub indikator makna}

Pada sub indikator ini terdapat 4 pertanyaan yang menjabarkan kesulitan mahasiswa mengenai makna. Dari analisis data yang telah dilakukan bahwasannya pada pada sub indikator makna termasuk pada kategori "sulit". Penjelasannya dapat dilihat pada tabel berikut:

\section{Sub indikator makna}




\begin{tabular}{|c|c|c|c|c|}
\hline $\begin{array}{c}\text { Sub } \\
\text { Indikator }\end{array}$ & Pertanyaan & Skor & $\begin{array}{c}\text { Skor } \\
\text { persen }\end{array}$ & Kategori \\
\hline & $\begin{array}{c}\text { Apakah Anda kesulitan } \\
\text { mencari ide pokok tiap } \\
\text { paragraf ketika membaca teks } \\
\text { bahasa Jepang pada mata } \\
\text { kuliah shochukyuu dokkai } \\
\text { zenhan? }\end{array}$ & 122 & $62,6 \%$ & Sulit \\
\hline Mal & $\begin{array}{c}\text { Apakah Anda kesulitan } \\
\text { memahami makna/pesan } \\
\text { yang tersurat pada setiap } \\
\text { teks bahasa Jepang pada mata } \\
\text { kuliah shochukyuu dokkai } \\
\text { zenhan? }\end{array}$ & & $59,5 \%$ & Sedang \\
\hline & $\begin{array}{l}\text { yang tersirat pada setiap teks } \\
\text { bahasa pada mata kuliah } \\
\text { shochukyuu dokkai zenhan? }\end{array}$ & 121 & & Sulit \\
\hline - & $\begin{array}{l}\text { Apakah Anda kesulitan } \\
\text { membuat kesimpulan } \\
\text { ketika membaca teks } \\
\text { bahasa Jepang pada mata } \\
\text { kuliah shochukyuu dokkai } \\
\text { zenhan? }\end{array}$ & 122 & $62,6 \%$ & Sulit \\
\hline & Rata-rata & 120,25 & $61,7 \%$ & sulit \\
\hline
\end{tabular}

Berdasarkan data tabel diatas dapat diketahui rata-rata kesulitan mahasiswa terhadap sub indikator makna berada dalam kategori "sulit" yaitu dengan persentase $61,7 \%$. Hal ini menyatakan bahwa mahasiswa tahun masuk 2018 merasa kesulitan dalam memahami makna yang disajikan di dalam teks bahasa Jepang shochukyuu dokkai zenhan. Dari tabel di atas juga dapat dilihat bahwa persentase skor mahasiswa sebanyak 62,6\% termasuk ke dalam kategori "sulit" untuk pertanyaan "Apakah Anda kesulitan mencari ide pokok tiap paragraf ketika membaca teks bahasa Jepang pada mata kuliah shochukyuu dokkai zenhan?" pada pertanyaan ini mahasiswa tahun masuk 2018 kesulitan dalam menemukan ide pokok tiap paragraf yang ada di dalam teks bahasa Jepang shochukyuu dokkai zenhan.

Untuk pertanyaan "Apakah Anda kesulitan memahami makna/pesan yang tersurat pada setiap teks bahasa Jepang pada mata kuliah shochukyuu dokkai zenhan?" pada tabel di atas dapat dilihat bahwa persentase skor mahasiswa sebanyak 59,5\% termasuk ke dalam kategori "sedang". Dalam pertanyaan ini persentase yang diperoleh hamper mendekati kategori sulit. Mahasiswa tahun masuk 2018 cukup merasa kesulitan dalam memahami pesan 
yang ada didalam teks bahasa Jepang. Karena kurang pahamnya dengan alur teks yang ada, pola kalimat yang sulit dipahami dan kanji yang tidak tahu artinya menjadikan mahasiswa sulit menangkap pesan yang terdapat di dalam teks bahasa Jepang shochukyuu dokkai zenhan.

Untuk pertanyaan "Apakah Anda kesulitan memahami makna/pesan yang tersirat pada setiap teks bahasa Jepang pada mata kuliah shochukyuu dokkai zenhan" pada tabel di atas dapat dilihat bahwa persentase skor mahasiswa sebanyak $62 \%$ termasuk ke dalam kategori "sulit". Artinya mahasiswa tahun masuk 2018 merasa kesulitan memahami pesan yang tersirat pada teks bahasa Jepang shochukyuu dokkai zenhan. Pada pembelajaran mahasiswa juga dituntut untuk memberikan tanggapan pesan yang tidak ada di dalam teks bahasa Jepang. Banyak sekali dari mahasiwa mampu membaca dan memahami isi teks tersebut tapi hanya sedikit mahasiswa yang mampu memahami pesan yang tidak tertulis di dalam teks bahasa Jepang.

Untuk pertanyaan "Apakah Anda kesulitan membuat kesimpulan ketika membaca teks bahasa Jepang pada mata kuliah shochukyuu dokkai zenhan?" pada tabel di atas dapat dilihat bahwa persentase skor mahasiswa sebanyak 62,6\% termasuk ke dalam kategori "sulit" artinya mahasiswa tahun masuk 2018 merasa kesulitan membuat kesimpulan pada teks bahasa Jepang yang telah dibaca.

\section{Indikator III (Pola Ejaan dan Bunyi)}

Salah satu indikator kesulitan mahasiswa dalam memahami teks bahasa Jepang adalah pola ejaan dan bunyi. Pada indikator ini terdapat 2 sub indikator. Deskripsi dari hasil analisis untuk indikator "pola ejaan dan bunyi" dapat dilihat pada tabel $13 \mathrm{di}$ bawah ini:

\section{Indikator pola ejaan dan bunyi}

\begin{tabular}{clccc} 
Indikator & \multicolumn{1}{c}{ Sub indikator } & Skor & Skor persen & Kategori \\
\hline & $\begin{array}{l}\text { Kecepatan membaca } \\
\text { yang fleksibel }\end{array}$ & 79 & $40,5 \%$ & Sedang \\
\cline { 2 - 5 } $\begin{array}{c}\text { Pola ejaan } \\
\text { dan bunyi }\end{array}$ & $\begin{array}{l}\text { Menyuarakan/ } \\
\text { intonasi dalam } \\
\text { membaca }\end{array}$ & 124 & $63,6 \%$ & Sulit \\
\hline Rata-rata & $\mathbf{1 0 1 , 5}$ & $\mathbf{5 2 \%}$ & Sedang
\end{tabular}

Berdasarkan data tabel diatas dapat diketahui rata-rata kesulitan mahasiswa terhadap indikator pola ejaan dan bunyi berada dalam kategori "sedang" yaitu dengan persentase 57,2\% termasuk ke dalam kategori "sedang" Selain itu, pada tabel di atas 
dapat diketahui bahwa dalam indikator pola ejaan dan bunyi terdapat 2 sub indikator yaitu Kecepatan membaca yang fleksibel dan Menyuarakan/intonasi dalam membaca . Adapun penjelasan mengenai sub indikator yang terdapat pada indikator ini adalah sebagai berikut:

\section{a. Sub Indikator Kecepatan membaca yang fleksibel}

Pada sub indikator ini terdapat 1 pertanyaan yang menjabarkan kesulitan mahasiswa mengenai Kecepatan membaca yang fleksibel. Dari analisis data yang telah dilakukan bahwasannya pada pada sub indikator Kecepatan membaca yang fleksibel termasuk pada kategori "sedang". Penjelasannya dapat dilihat pada tabel berikut:

\section{Sub indikator Kecepatan membaca yang fleksibel}

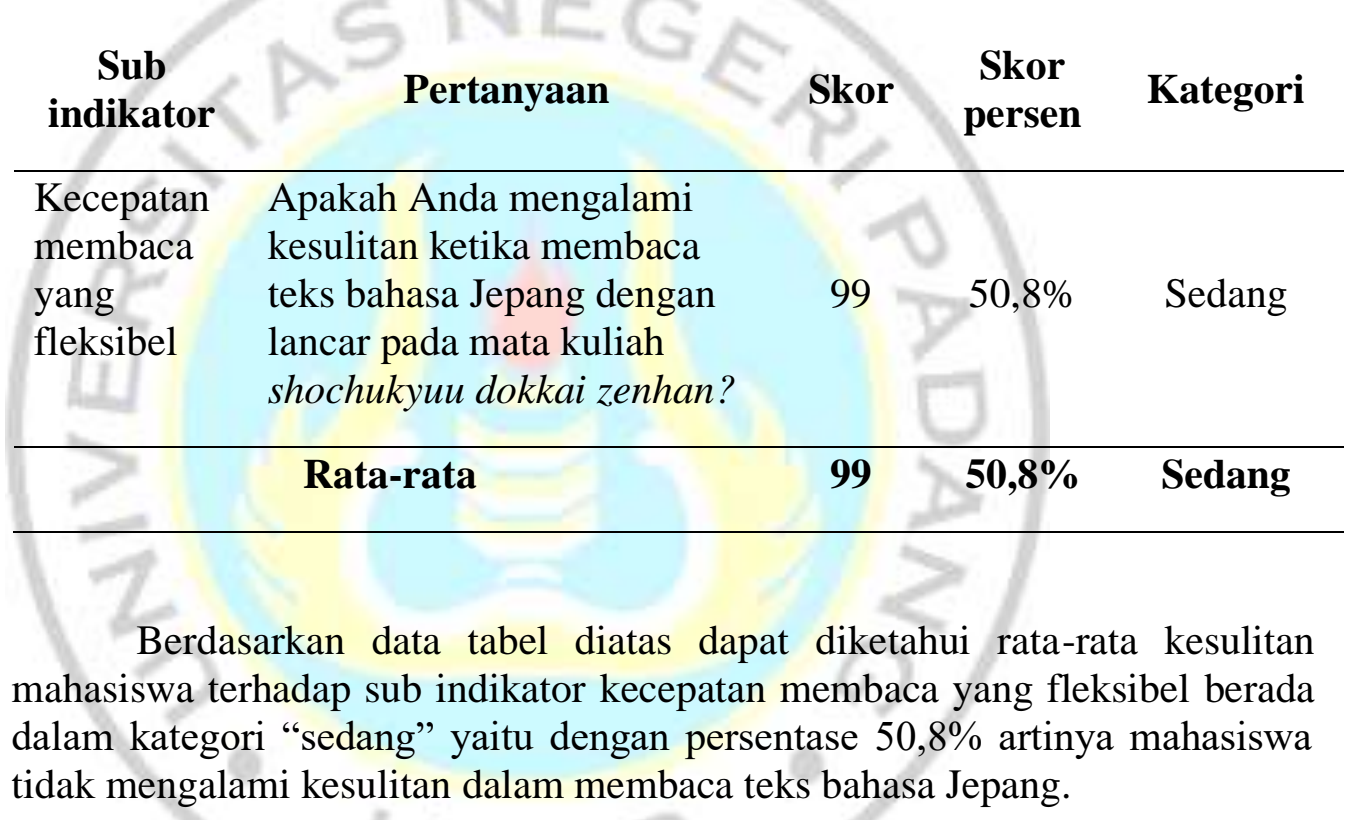

\section{b. Sub indikator menyuarakan /intonasi dalam membaca}

Pada sub indikator ini terdapat 1 pertanyaan yang menjabarkan kesulitan mahasiswa mengenai menyuarakan /intonasi dalam membaca. Dari analisis data yang telah dilakukan bahwasannya pada pada sub indikator inil termasuk pada kategori "sulit". Penjelasannya dapat dilihat pada tabel berikut:

\section{Sub indikator intonasi dalam membaca}

\begin{tabular}{llccc} 
Sub indikator & \multicolumn{1}{c}{ Pertanyaan } & Skor & $\begin{array}{c}\text { Skor } \\
\text { persen }\end{array}$ & Kategori \\
\hline $\begin{array}{l}\text { Menyuarakan/ } \\
\text { intonasi dalam } \\
\text { membaca }\end{array}$ & $\begin{array}{l}\text { Apakah Anda mengalami } \\
\text { kesulitan ketika membaca } \\
\text { teks bahasa Jepang dengan } \\
\text { intonasi yang tepat pada }\end{array}$ & 124 & $63,6 \%$ & Sulit \\
\hline
\end{tabular}


mata kuliah shochukyuu

dokkai zenhan?

$\begin{array}{llll}\text { Rata-rata } & 124 & 63,6 \% & \text { Sulit }\end{array}$

Berdasarkan data tabel diatas dapat diketahui rata-rata kesulitan mahasiswa terhadap sub indikator Menyuarakan/intonasi dalam membaca berada dalam kategori "sulit" yaitu dengan persentase $63,6 \%$ artinya bahwa mahasiswa kesulitan membaca dengan intonasi yang tepat saat membaca teks bahasa Jepang shochukyuu dokkai zenhan

\section{Pembahasan}

Berdasarkan data di atas indikator huruf berada dalam kategori "sedang". diketahui bahwa dalam indikator huruf terdapat 3 sub indikator yaitu hiragana, katakana, dan kanji. Dalam indikator huruf ini sub indikator kanji berada dalam katekogiri "sulit" Hal ini menyatakan bahwa mahasiswa tahun masuk 2018 merasa kesulitan dangan huruf kanji yang ada dalam shochukyuu dokkai zenhan. Kanji merupakan huruf yang sulit untuk di hafal karena memiliki cara baca yang lebih dari satu (on yomi dan kun yomi), banyaknya variasi kanji dan juga memiliki bentuk dengan coretan (kakusuu) yang banyak dan rumit yang membuat sulit untuk dibaca. Dalam tingkatan shochukyuu dokkai zenhan ini, banyaknya kanji yang sulit karena masih banyak mahasiswa yang belum mengetahui kanji yang disajikan di dalamnya. Namun tentu saja dalam pembelajaran mata kuliah shochukyuu dokkai zenhan mahasiwa harus dituntun untuk mengetahui bacaan kanji tersebut. Oleh sebab itu mahasiswa masih mengalami kesulitan saat membaca kanji, ini juga berdampak ketika mahasiswa memahami teks bahasa Jepang. Selain membaca huruf kanji, mahasiswa juga kesulitan saat mengetahui arti dari huruf kanji yang ada dalam teks bahasa Jepang shochukyuu dokkai zenhan. Banyaknya huruf kanji yang harus diingat dan dihafal mahasiswa menjadi kesulitan mengetahui arti kanji yang ada di dalam teks bahasa Jepang shochukyuu dokkai zenhan, ini sangat berdampak dalam memahami teks bahasa Jepang. Oleh sebab itu mahasiswa harus mengetahui arti dari huruf kanji terlebih dahulu sebelum memahami teks bahasa Jepang.

Berdasarkan data di atas dinyatakan bahwa rata-rata mahasiswa kesulitan di semua indikator linguistik. Pada sub indikator kosakata berada dalam kategori "sulit" kecuali pada pertanyaan "Apakah Anda kesulitan memahami kosakata baru yang diajarkan disetiap materi pada mata kuliah shochukyuu dokkai zenhan?" dalam kategori "sedang". Banyaknya mahasiswa kesulitan pada sub indikator kosakata ini karena tidak mengetahui arti kosakata yang belum dipelajari, kesulitan menemukan arti kosakata karena tidak semua kosakata terdapat di dalam kamus dan sulitnya menemukan padanan dalam bahasa Indonesia. Inilah hal-hal yang membuat mahasiswa kesulitan pada kosakata dalam memahami teks bahasa Jepang shochukyuu dokkai zenhan. Pada sub indikator pola kalimat berada dalam kategori "sulit" ini menyatakan mahasiswa kesulitan dalam pola kalimat antara lain banyaknya pola kalimat yang belum dipelajari, sulit dalam menerjemahkan kalimat panjang karena perbedaan struktur dengan kalimat Indonesia, sulit menentukan subjek pada kalimat 
dan terdapat partikel yang tidak ada di dalam teks bahasa Indonesia. Ini sangat berdampak bagi mahaasiswa dalam memahami teks bahasa Jepang shochukyuu dokkai zenhan.

Pada sub indikator makna berada dalam kategori "sulit" Hal ini menyatakan bahwa mahasiswa tahun masuk 2018 merasa kesulitan dalam memahami makna yang disajikan di dalam shochukyuu dokkai zenhan. Makna di dalam pertanyaan ini meliputi ide pokok, pesan yang tersirat maupun yang tersurat dan kesimpulan. Biasanya untuk mengetahui apakah seorang mahasiswa mampu memahami isi dari teks bahasa Jepang akan ada pertanyaan tentang ide pokok, pesan, dan kesimpulan di akhir sebuah teks. Untuk menjawab pertanyaan tersebut mahasiswa terlebih dahulu harus memahami isi dari teks bahasa Jepang shochukyuu dokkai zenhan. Kurangnya penguasaan pada kosakata, pola kalimat dan huruf yang sudah dijelaskan di atas tentu saja sangat sulit mencari ide pokok didalamnya karena tidak bisa memahami teks tersebut. Begitu pula dengan mencari pesan yang tersurat maupun yang tersirat apa yang disampaikan oleh pengarang di dalam teks bahasa Jepang shochukyuu dokkai zenhan karena pada setiap teks selalu menyajikan hal tersebut. Oleh sebab itu mahasiswa harus mengerti dengan teks yang dibacanya sebelum menemukan pesan tersebut. Dan karena kurang pahamnya dengan alur teks yang ada, itu menjadikan mahasiswa sulit membuat kesimpulan pada teks bahasa Jepang. Pada kasus ini mahasiswa tidak jarang merasa kesulitan untuk membuat kesimpulan sendiri. Ini artinya bahwa banyak mahasiswa hanya mampu membaca teks bahasa Jepang tapi tidak bisa memahami teks bahasa Jepang tersebut.

Pada indikator pola ejaan dan bunyi berada dalam kategori "sedang", diketahui pada indikator ini terdapat 2 sub indikator yaitu sub indikator Kecepatan membaca yang fleksibel dan sub indikator Menyuarakan/intonasi. Pada sub indikator menyuarakan/intonasi dalam membaca diketahui berada dalam kategori "sulit". Hal ini menyatakan bahwa mahasiswa tahun masuk 2018 merasa kesulitan dangan menyuarakan dengan intonasi yang tepat ketika membaca teks Bahasa Jepang. Berbedanya intonasi/ logat dalam tindak tutur bahasa Jepang dengan Indonesia menyebabkan mahasiswa menjadi kesulitan. Jadi sebelum membaca mahasiswa harus bisa mencari Perjedaan antara kata dengan kata lain pada satu kalimat dalam bahasa Jepang, mencermati situasi yang terdapat di dalam cerita agar dapat mengetahui nada tinggi atau rendah, panjang dan pendeknya suatu kata, karena itu harus diperhatikan sebelum membaca dengan intonasi yang tepat. Hal ini sangat penting karena dalam bahasa Jepang terdapat kosakata yang sama tetapi berbeda cara pengucapannya.

\section{KESIMPULAN}


1. Dari hasil persentase di atas kesulitan mahasiswa tahun masuk 2018 UNP dalam memahami tesk bahasa Jepang mengalami kesulitan pada hampir semua sub indikator yang ada.

2. Kesulitan mahasiswa prodi pendidikan bahasa Jepang tahun masuk 2018 dalam memahami teks bahasa Jepang UNP ditinjau dari indikator huruf yang mana pada sub inikator kanji sangat mendominasi kesulitannya yaitu sebesar 74,3\%. Hal ini sangat mempengaruhi kesulitan mahasiswa dalam memahami teks bahasa Jepang.

3. Mahasiswa tahun masuk 2018 juga mengalami kesulitan pada indikator lingustik yang terdapat sub indikator kosakata, pola kalimat dan makna. Hal ini juga sangat penting dalam memahami teks bahasa Jepang

\section{REFERENSI}

Arikunto, Suharsimi. 2010. Prosedur Penelitian Suatu Pendekatan Praktik. Edisi Revisi. Jakarta: Rineka Cipta

Dalman. 2013. Keterampilan Membaca. Jakarta: Raja Grafindo Persada.

Lidra, Harviko., Putri, Meira Anggia., \& Yani, Damai. 2018. "Kemampuan Penggunaan Jodoushi-Souda pada Mahasiswa Tingkat III Pendidikan Bahasa Jepang UNP”. Omiyage : Jurnal Bahasa Dan Pembelajaran Bahasa Jepang. Vol. 1, No.3.

Sugiyono, 2016. Metode Penelitian Kuantitatif, Kualitatif dan R\&D, Bandung: Alfabeta

Sutedi, Dedi. 2009. Pengantar Penelitian Pendidikan Bahasa Jepang. Bandung: Jurusan Pendidikan Bahasa Jepang FPBS UPI.

Tarigan, Henry Guntur. 2006. Membaca Sebagai Suatu Keterampilan Berbahasa. Bandung : Percetakan Angkasa. 